\title{
PERSONALITY TYPOLOGY IN PATIENTS WITH TRAUMATIC LIMB FRACTURES
}

\author{
Sime Trpeski ${ }^{1}$, Nada Pop-Jordanova ${ }^{2}$ \\ ${ }^{1}$ University Traumatology Clinic, Faculty of Medicine, Skopje, Republic of Macedonia \\ ${ }^{2}$ Macedonian Academy of Science and Arts, Skopje, Republic of Macedonia
}

Corresponding author: Nada Pop-Jordanova, E-mail: popjordanova.nadica@gmail.com

\section{ABSTRACT}

The notion that personality impacts health is not new. According to Grossarth-Maticek and Eysenck's theoretical approach, the main factor for health is the ability for self-regulation, which seems to moderate the effects of some physical risk factors.

The aim of this study was to evaluate personality characteristics of patients hospitalized for traumatic limb's fractures which have been operatively treated. To our knowledge, it is the first study of this type in the region.

The evaluated sample comprises two groups of examinees: patients hospitalized at the Traumatology Clinic for surgery after fractured limbs $(\mathrm{N}=30)$ and healthy people $(\mathrm{N}=120)$ as control, previously examined. Two psychometric tests were used: Grossarth-Maticek questionnaire and Eysenck Personality Questionnaire (EPQ).

Obtained results showed that the personality characteristics of patients with traumatic limb fractures belong generally to the "healthy type 4" of Grossarth-Maticek typology, similarly as the control. It correlates to the low N (neuroticism) and moderate E (extraversion) scales in the Eysenck typology.

We showed that gender and age highly influence the scores obtained from the questionnaire.

The type of personality could influence reactions in life situations, coping with stress and consequently to be a trigger for any disorder, even traumatic fractures

Keywords: traumatic fractures, personality type, stress.

\section{INTRODUCTION}

Psychological profiling may be described as a method which seeks to identify a person's mental, emotional, and personality characteristics. The notion that personality impacts health is not new. Most studies that address this issue were unable to distinguish between personality traits as rick factors, or as byproducts of the disease. In the psychosomatic approach, the most popular typology related to disease proneness is that which divided people in two main types: A and B. Large number of studies aimed to prove this concept (Friedman, 1996; Kuper, 2002; Petticrew, 2012; McLeod, 2013).

Type A individuals tend to be very competitive and self-critical. They strive toward goals without feeling a sense of joy in their efforts or accomplishments. As a consequence, this type happened to be prone to coronary diseases. People with type B personality tend to be more tolerant of others, are more relaxed than type A individuals, 
more reflective, experience lower levels of anxiety and display higher level of imagination and creativity.

The general opinion is that personality may influence health through at least two non-exclusive processes. The first predisposes the individual to behaviours that include both unhealthy (such as alcohol, tobacco, and other drugs consumption) and healthy habits (e.g. physical exercise or good diet). The second influences by means of the person's coping style that indirectly affects health, which is in all likelihood mediated by hormonal and physiological factors related to the immunological and cardiovascular systems (Eysenck, 1991; Ader, 1991).

However, most of the research interest about personality and health has been directed towards the cancer-prone personality and the coronary heart disease (CHD)-prone personality contrasted with the healthy type. These concepts include different behaviours and coping processes that result in an increased risk of disease or in a more healthy way of behaving and reacting to different stressors. In general, these different approaches to disease-prone and healthy personalities have a great deal in common.

Grossarth-Maticek and colleagues (1990; 1991) have shown, in their prospective studies in ex-Yugoslavia and Germany, a strong relationship of personality Types 1 and 2, with cancer and coronary heart disease (CHD), respectively.

The results of very larges studies in this context show that low neuroticism and extraversion (dimensions from Eysenck personality theory) are clearly related to Type 4 (healthy), whereas neuroticism and introversion correlate with Type 1 (cancer-prone) and Type 2 (CHD-prone). Thus, the scales related to Types 1 and 2 gathered the disease-prone pole of this dimension, while Type 4 related scales represent the opposite healthy/autonomous-prone pole of the factor.

According to Grossarth-Maticek and Eysenck's theoretical approach, the main factor for health is the ability for self-regulation, which seems to moderate the effects of some physical risk factors (e.g. smoking, drinking alcohol). Thus, although physical risk factors are clearly related to health, psychological risk factors (e.g. low self-regulation coping) could also have deleterious effects on health, both having synergic or multiplicative role (Grossarth-Maticek, Eysenck, $\&$ Boyle, 1995; 2000). In this context, the authors found that the increase of self-regulation ability by means of autonomy training, a kind of behavioural-cognitive therapy, improved the health related habits of the probands and significantly reduced mortality. As a coping method, self-regulation should be closely related to basic personality traits. A higher self-regulation was associated with emotional stability (low N) and extraversion and, to a lesser degree, with impulse control (low P).

The aim of this study was to evaluate personality characteristics of patients hospitalized for traumatic limb's fractures which have been operatively treated. To our knowledge, it is the first study of this type in the region; similar studies do not exist in our country.

\section{METHODS AND SAMPLE}

The evaluated sample comprises two groups of examinees: (a) patients hospitalized at the Traumatology Clinic for surgery after fractured limbs $(\mathrm{N}=30)$ and (b) healthy people $(\mathrm{N}=120)$ as control, previously examined.

As psychometric instruments we used the Grossarth-Maticek questionnaire (1990), applied for the first time in our country. The questionnaire was obtained with the courtesy of the author many years ago, and it was translated in Macedonian language and validated for use.

It contains six scales corresponding to six personality types prone to different types of disease, which may be characterized as follows: (1) Marked inhibitions in the expression of emotions and the satisfaction of personal desires and needs (2) Behavior characterized by inner excitement and agitation, such as anger (3) Self-absorption and selfish behavior (4) Flexibility of self-regulation; internality (5) Rational and anti-emotional behavior (6) Aggressive and psychopathic behavior. Table 1 shows the original description of the six personality types. 
Table I. Description of the six personality types

[From H. J. Eysenck (1991), Smoking, Personality and Stress: Psychosocial Factors in the Prevention of Cancer and Coronary Heart Disease. London: Springer].

Types Description and characterization

Type I Cancer-prone: characterized by (i) suppression of emotion (ii) failure to successfully cope with stress which leads to feelings of hopelessness, helplessness, and depression (iii) appeasing, unassenive, over-cooperative, compliant and defensive

Type 2 Coronary heart disease (CHD) prone: angry, hostile, aggressive, overaroused

Type 3 Alternating reaction type: psychopathic, characterised by ambivalence. Alternates between type 1 and type 2

Type 4 Autonomous, healthy type: able to show emotion, capable of controlling stress T

Type 5 Rational-antiemotional type: related to rheumatoid arthritis and cance Type 6 Anti-social egocentric type: psychopathic, drug-addictive, possibly criminal

As can be seen, Type 1 corresponds to alexitimic traits of personality or "pensée operatoire" as described by French psychologists. Type 2 is similar to classical Type A, described before.

According to Grossarth-Maticek, a person is considered to be "stressed" when obtained scores for scales $1+2+5>3+4+6$.

Additionally, in this research we used another psychometric instrument - the Eysenck Personality Questionnaire (EPQ).

The EPQ was chosen to examine the four classical characteristics of personality: $\mathrm{N}$, level of emotional stability/neuroticism; $\mathrm{E}$, dimension of extraversion/introversion; $\mathrm{P}$, dimension of psychotic behavior; and L, degree of dissimulation or social adaptability. Our previous experience with this instrument confirmed the validity, reliability and discriminability of the obtained results. $[19,20]$

The hypothesis of our research was to correlate disease proneness evaluated with the Grossarth-Maticek typology with the proneness to traumatic injuries. Additionally, main personality characteristics evaluated with EPQ will confirm the proneness to trauma based on bad coping mechanism.

\section{RESULTS}

The age of male patients was $41,16 \pm$ 17.82 and for females $60.5 \pm 13.46$ years. Both genders were included equally $(15+15=30$ in total). All examinees had traumatic fractures of limbs operatively treated; in this context, several days of hospitalization were needed. During this period after surgery the psychometric tests were applied. For control, mean age for males was $47.6 \pm 89.5$ years and for females $37.35 \pm$ 11.3 years.

Obtained results for EPQ separately for males and females are displayed in Fig. 1.

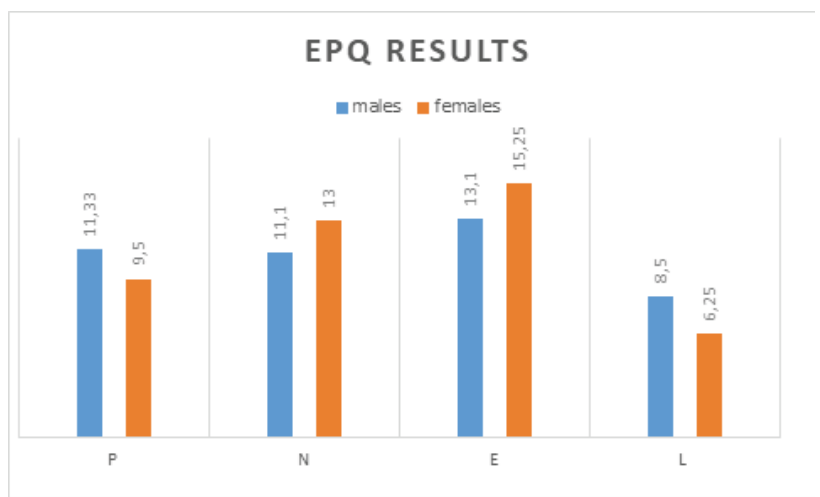

Figure 1. EPQ in patients with fractures

As can be seen, moderate extraversion in both genders, small psychopathological traits, small neurotic tendencies and $\mathrm{L}$ scale in relatively "normal" ranges were our findings. In the original Eysenck's studies a higher self-regulation was associated with emotional stability (low $\mathrm{N}$ ) and extraversion and, to a lesser degree, with impulse control (low P) which could be seen in our patients too.

The typology of patients tested with the Grossarth-Maticek questionnaire is presented in Fig. 2; while the typology obtained for healthy people is presented in Fig. 3

TYPOLOGY OF PATIENTS

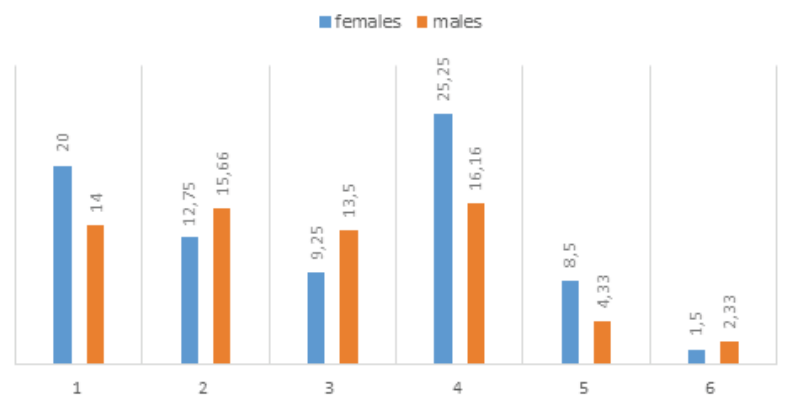

Figure 2. Patient's typology 
Typology in healthy males and females

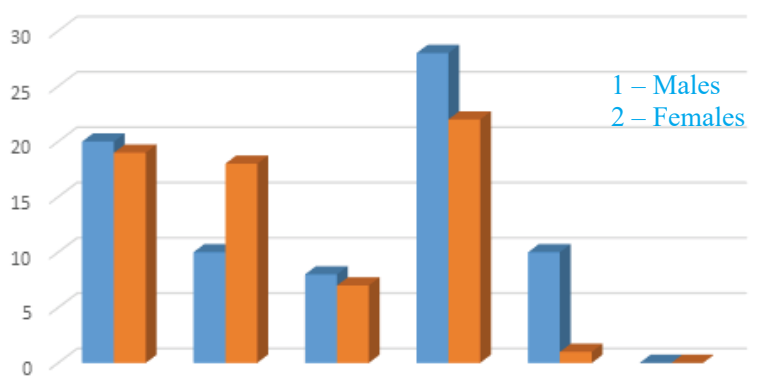

Figure 3. Typology in healthy people

Table 2. ANOVA for age and all 6 type personalities

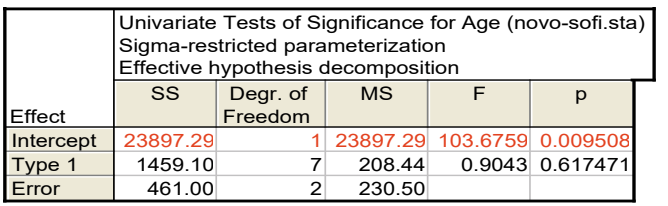

\begin{tabular}{|l|r|r|r|r|c|}
\hline \multirow{5}{*}{ Effect } & \multicolumn{5}{|l|}{$\begin{array}{l}\text { Univariate Tests of Significance for Age (novo-sofi.sta) } \\
\text { Sigma-restricted parameterization } \\
\text { Effective hypothesis decomposition }\end{array}$} \\
\cline { 2 - 7 } & $\mathrm{SS}$ & $\begin{array}{l}\text { Degr. of } \\
\text { Freedom }\end{array}$ & MS & $\mathrm{F}$ & $\mathrm{p}$ \\
\hline Intercept & 25255.15 & 1 & 25255.15 & 168.7051 & 0.000048 \\
\hline Type 3 & 1171.60 & 4 & 292.90 & 1.9566 & 0.239611 \\
\hline Error & 748.50 & 5 & 149.70 & & \\
\hline
\end{tabular}

\begin{tabular}{|l|r|r|r|c|c|}
\hline \multirow{2}{*}{ Effect } & \multicolumn{5}{|l|}{$\begin{array}{l}\text { Univariate Tests of Significance for Age (novo-sofi.sta) } \\
\text { Sigma-restricted parameterization } \\
\text { Effective hypothesis decomposition }\end{array}$} \\
\cline { 2 - 6 } & SS & $\begin{array}{r}\text { Degr. of } \\
\text { Freedom }\end{array}$ & MS & F & p \\
\hline Intercept & 18321.05 & 1 & 18321.05 & 152.0419 & 0.000249 \\
\hline Type 5 & 1438.10 & 5 & 287.62 & 2.3869 & 0.209862 \\
\hline Error & 482.00 & 4 & 120.50 & & \\
\hline
\end{tabular}

Table 3. ANOVA for gender differences in all types

\begin{tabular}{|l|r|r|r|r|r|}
\hline \multirow{2}{*}{ Effect } & \multicolumn{6}{|l|}{$\begin{array}{l}\text { Univariate Tests of Significance for Gender (novo-sofi.sta) } \\
\text { Sigma-restricted parameterization } \\
\text { Effective hypothesis decomposition }\end{array}$} \\
\cline { 2 - 7 } & $\mathrm{SS}$ & $\begin{array}{r}\text { Degr. of } \\
\text { Freedom }\end{array}$ & MS & $\mathrm{F}$ & $\mathrm{p}$ \\
\hline Intercept & 96174.32 & 1 & 96174.32 & 384697.3 & 0.000003 \\
\hline Type 1 & 1.90 & 7 & 0.27 & 1.1 & 0.558533 \\
\hline Error & 0.50 & 2 & 0.25 & & \\
\hline
\end{tabular}

\begin{tabular}{|l|r|r|r|r|r|r|}
\hline \multirow{2}{*}{ Effect } & \multicolumn{6}{|l|}{$\begin{array}{l}\text { Univariate Tests of Significance for Gender (novo-sofi.sta) } \\
\text { Sigma-restricted parameterization } \\
\text { Effective hypothesis decomposition }\end{array}$} \\
\cline { 2 - 6 } & $\mathrm{SS}$ & $\begin{array}{r}\text { Degr. of } \\
\text { Freedom }\end{array}$ & MS & F & $\mathrm{p}$ & \\
\hline Intercept & 92943.54 & 1 & 92943.54 & 398329.5 & 0.000000 \\
Type 3 & 1.23 & 4 & 0.31 & 1.3 & 0.376420 \\
Error & 1.17 & 5 & 0.23 & & \\
\hline
\end{tabular}

\begin{tabular}{|c|c|c|c|c|c|}
\hline \multirow[b]{2}{*}{ Effect } & \multicolumn{5}{|c|}{$\begin{array}{l}\text { Univariate Tests of Significance for Gender (novo-sofi.sta) } \\
\text { Sigma-restricted parameterization } \\
\text { Effective hypothesis decomposition }\end{array}$} \\
\hline & SS & \begin{tabular}{|c|} 
Degr. of \\
Freedom
\end{tabular} & MS & $\mathrm{F}$ & $p$ \\
\hline Intercept & \begin{tabular}{|l|}
79950.33 \\
\end{tabular} & 1 & 79950.33 & 426401.8 & 0.000000 \\
\hline Type 5 & 1.65 & 5 & 0.33 & 1.8 & 0.301918 \\
\hline Error & 0.75 & 4 & 0.19 & & \\
\hline
\end{tabular}

In healthy people we obtained predominant Type 4 personality (healthy). However, females happened to belong also in Type 1 and 2 which is similar to the group of patients.

Opposite to healthy males, obtained results for female patients with fractures are very similar, i.e. the predominant is the "healthy" Type 4, but also Type 1 is relatively high; while in male patients we obtained similar scores for 1, 2, 3 and 4 personality type. It means that males could be disease prone (for cancer, cardiovascular diseases as well as for alternative type - between 1 and 2). It means that males are "more prone" to serious diseases than females.

\begin{tabular}{|l|r|r|r|r|c|}
\hline \multirow{5}{*}{ Effect } & \multicolumn{5}{|l|}{$\begin{array}{l}\text { Univariate Tests of Significance for Age (novo-sofi.sta) } \\
\text { Sigma-restricted parameterization } \\
\text { Effective hypothesis decomposition }\end{array}$} \\
\cline { 2 - 7 } & $\mathrm{SS}$ & $\begin{array}{r}\text { Degr. of } \\
\text { Freedom }\end{array}$ & MS & $\mathrm{F}$ & $\mathrm{p}$ \\
\hline Intercept & 24308.04 & 1 & 24308.04 & 892.0380 & 0.001119 \\
\hline Type 2 & 1865.60 & 7 & 266.51 & 9.7803 & 0.095869 \\
\hline Error & 54.50 & 2 & 27.25 & & \\
\hline
\end{tabular}

\begin{tabular}{|l|r|r|r|r|c|}
\hline \multirow{5}{*}{ Effect } & \multicolumn{5}{|l|}{$\begin{array}{l}\text { Univariate Tests of Significance for Age (novo-sofi.sta) } \\
\text { Sigma-restricted parameterization } \\
\text { Effective hypothesis decomposition }\end{array}$} \\
\cline { 2 - 7 } & $\mathrm{SS}$ & $\begin{array}{r}\text { Degr. of } \\
\text { Freedom }\end{array}$ & MS & $\mathrm{F}$ & $\mathrm{p}$ \\
\hline Intercept & 25320.14 & 1 & 25320.14 & 52.47698 & 0.018528 \\
\hline Type 4 & 955.10 & 7 & 136.44 & 0.28278 & 0.913196 \\
\hline Error & 965.00 & 2 & 482.50 & & \\
\hline
\end{tabular}

\begin{tabular}{|l|r|r|r|r|r|}
\hline \multirow{4}{*}{ Effect } & \multicolumn{6}{|l|}{$\begin{array}{l}\text { Univariate Tests of Significance for Age (novo-sofi.sta) } \\
\text { Sigma-restricted parameterization } \\
\text { Effective hypothesis decomposition }\end{array}$} \\
\cline { 2 - 7 } & $\mathrm{SS}$ & $\begin{array}{r}\text { Degr. of } \\
\text { Freedom }\end{array}$ & MS & $\mathrm{F}$ & $\mathrm{p}$ \\
\hline Intercept & 22248.52 & 1 & 22248.52 & 87.72211 & 0.000724 \\
\hline Type 6 & 905.60 & 5 & 181.12 & 0.71413 & 0.645442 \\
\hline Error & 1014.50 & 4 & 253.63 & & \\
\hline
\end{tabular}
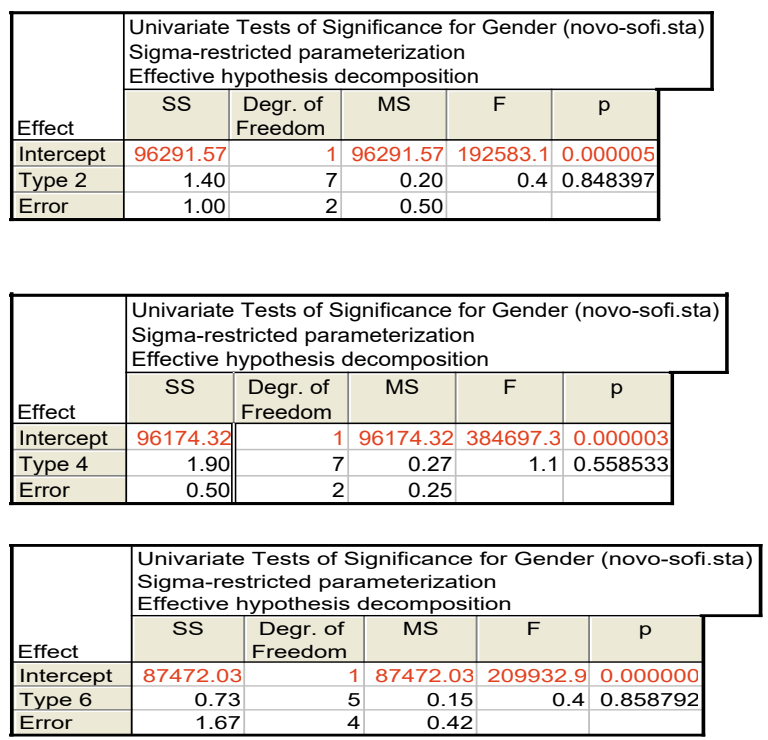
Concerning stress, our examinees showed stress-related states (sum of $1+2+5>3+4+$ 6 ), which seems very logical to us. Stress could be provocation for fractures, but also the reverse interpretation is possible - the situation after fractures provokes high stress level.

Calculated one way ANOVA showed statistical significance of variance in obtained scores for all 6 personality types for different ages (Table 2).

Additionally, calculated one way ANOVA confirmed the statistical significance of gender for scores obtained for all types of personalities (Table 3).

So, this statistics confirmed that scores obtained significantly depend on age and gender.

If we compare Eysenck personality scores (low $\mathrm{N}$, moderate $\mathrm{E}$, and low $\mathrm{P}$ ) with Grossarth-Maticek typology (predominantly type 4 for females, non-differentiated types for males) we can find some logical interpretations: patients with traumatic fractures belong generally to the healthy type 4 of personality. High stress, according to calculations of obtained scores could be related to the state of patients (fractures which provoked immobilization and exclusion from everyday life, as well as hospitalization and operative treatment).

In our previous research (Pop-Jordanova et all., 2015), we examined the perceived stress tested by PSQ (perceived stress questionnaire) in a group of patients hospitalized also at the Traumatology Clinic. The mean age of patients was $36.8 \pm 13.9$ years (both genders included equally) and the obtained scores for PSQ were pretty high $(0.52 \pm 0.9)$. These results have been the highest ones compared with the scores obtained for doctors and nurses tested at the same clinic with the same test (ANOVA one way was highly significant $\mathrm{F}=3 ; \mathrm{p}=0.01$ ). We obtained very high negative correlation between the age and the obtained PSQ scores, which means that with the age, patients cope better with the stress. No correlation was obtained between gender and scores obtained for PSQ in this study.

By definition, traumatology is a branch of surgery dealing with major wounds caused by accidents. So, our interest in researching stress and personality profiles in these patients and staff was logical.

As we showed, stress in patients is pretty high, and although they belong to the "healthy" personality profiles, consequences could be related to this high stress level.

\section{DISCUSSION}

In contemporary medicine there is a growing recognition that mental states can significantly affect physical health by inhibiting the immune system and/or causing particular damage to cardiovascular reactions. Primitive emotional responses can alter virtually all of the body's homeostatic regulating systems in ways that significantly affect physical health. The exact nature of these interactions is only poorly understood, but the relationship between psychosocial stress and many illnesses is clearly demonstrated.

Practically all studies of neuroendocrine interactions with health have been focused on the negative effects of stress. The stress response is mediated by the hippocampus via the hypothalmus, pituitary and adrenal cortex. It results in increased cortisol production and weakened immunity during feelings of helpless stress. Elevated risk for cancer promotion and infectious diseases can be the result.

Research conducted over the last 50 years indicates a modest role of psycho-social factors as risk factors for these conditions. However, the research suggests that in combination with other risk factors, psycho-social factors play an equally important role. In this context, Grossarth-Maticek \& Eysenck (1990) conducted the largest long term prospective psychological health study. They monitored around 20,000 probands for 15 years in order to determine the relative contributions to health outcomes (primarily cancer and CHD) of standard medical and psycho-social risk factors. They reported an $81 \%$ accuracy of prediction of death by cancer or CHD with the use of a psychometric test. Further, answers to the test were reported to be six times more predictive of cancer or CHD than were any of the standard medical risk factors, either taken on their own or together.

This mind/body approach is also prevalent in more recent studies. For example, Absetz et al. (2002) in a representative sample of middle aged Finnish women evaluated factors associated with breast cancer risk perception and psychological distress. Additionally, Strójwąs et al. (2016) in the same context examined emotional and psychosomatic disorder among female patients undergoing breast cancer diagnosis and found some relationships. 
In the newer times, using neuroimaging technologies the brain's default network has been a topic of considerable interest. In this context, studies tried to find a biological basis for some personal characteristics (e.g. openness to experience), and suggest that normally distributed personality traits affect the intrinsic architecture of large-scale brain systems (Beaty et al. 2016). Additionally, resting-state functional connectivity, as measured by functional magnetic resonance imaging (fMRI), treated as a trait is used to draw inferences about individual differences in cognitive function, or differences between healthy or diseased populations (Geerligs et al. 2015). These evaluations of brain characteristics and personality traits could be some proofs about the "psychosomatic theoretical approach" for the relationship between the mind and the body.

Still, medical scientists were justifiably sceptical of any link between personality and disease, and have been trying to test if personality traits contribute to illness or if illness causes personality traits. It is evident that the earliest studies linking personality to disease were observational, involving individuals who already were sick.

In our two studies devoted to the personality characteristics in patients at the Traumatology Clinic we confirmed that even in the "normal/ healthy" personality type, the high level of stress could be related to traumatic events and fractures. The reverse relation is also possible. However, the personality must not be ignored when medical staff works with any kind of disorders.

\section{CONCLUSION}

In psychosomatic medicine there is a growing recognition that mental states can significantly affect physical health. In addition, personality traits are also influential.

The personality characteristics of patients with traumatic limb fractures belong generally to the "healthy type 4" of the Grossartgh-Maticek typology. It correlates to the low $\mathrm{N}$ and moderate E scales of the Eysenck typology.

The stress level in all patients is high.

We showed that gender and age highly influence the scores obtained with the questionnaire.
The type of personality could influence reactions in real life situations, coping with stress and consequently be a trigger for any disorder, even traumatic fractures.

\section{REFERENCES}

1. Absetz P., Arja A., \& Sutton S. Factors associated with breast cancer risk perception and psychological distress in a representative sample of middle aged Finnish women. Anxiety, Stress and Coping, 2002, Vol.15, No.1, pp. 61-73.

2. Ader R. et al. Psychoneuroimmunology 2nd edition. San Diego, CA: Academic Press, 1991, xxv.

3. Beaty RE, Kaufman SB, Benedek M, Jung RE, Kenett YN, Jauk E, Neubauer AC, Silvia PJ. Personality and complex brain networks: The role of openness to experience in default network efficiency. Hum Brain Mapp. 2016; 37(2) pp. 773-9

4. Eysenck H. J. "Type A Behavior and Coronary Heart Disease: The Third Stage". Journal of Social Behavior and Personality 1990, 5: 25-44.

5. Eysenck HJ, Eysenck SBJ. Manual of the Eysenck Personality Questionnaire. Hodder and Stoughton, London, 1975

6. Eysenck H. Personality, stress, and disease: an interactionist perspective. Psychological Inquiry. 1991b, Vol. 2, No. 3, pp. 221-232.

7. Eysenck H. Prediction of cancer and coronary heart disease mortality by means of a personality inventory: results of a 15 year follow up study. Psychological Reports. 1993, Vol. 72, pp. 499-516.

8. Eysenck H. Cancer, personality and stress: prediction and prevention. Advanced Behaviour Therapy and Research. 1994, Vol. 16, pp. 167-215.

9. Fahlgren E, Nima AA, Archer T, Garcia D. Person-centered osteopathic practice: patients' personality (body, mind, and soul) and health (ill-being and well-being). PeerJ. 2015 Oct 27;3:e1349. doi: 10.7717/peerj.1349. eCollection 2015.

10. Friedman, M. Type A Behavior: Its Diagnosis and Treatment. New York: Plenum Press (Kluwer Academic Press), 1996.

11. Geerligs L, Rubinov M, Cam-Can, Henson RN. State and Trait Components of Functional Connectivity: Individual Differences Vary with Mental State. J Neurosci. 2015, 14; 35(41):13949-61.

12. Grossarth-Maticek R.; Eysenck H. J. Creative Novation Behaviour Therapy as a Prophylactic 
Treatment for Cancer and Coronary Heart Disease: I. Description of Treatment. Behaviour Research and Therapy. 1991, 29: 1-16.

13. Grossarth-Maticek R. et al. Interpersonal Repression as a Predictor of Cancer. Social Science \& Medicine, 1982, 16, pp. 493-498.

14. [Grossarth-Maticek R, Eysenck H. Personality, Stress and Disease: description and validation of a new inventory. Psychological Reports. 1990, 66, pp. 355-373.

15. Grossarth-Maticek R, Eysenck HJ, Boyle G. Method of test administration as a factor in test validity: the use of a personality questionnaire in the prediction of cancer and coronary heart disease. Behaviour Research and Therapy, 1995, Vol 33, No. 6 pp. 705-710.

16. Kuper, H.; M. Marmot; H. Hemingway. Systematic review of prospective cohort studies of psychosocial factors in the etiology and prognosis of coronary heart disease. Seminars in Vascular Medicine. 2002; 2 (3): 267-314.

17. McLeod, Saul. Type A Personality. Retrieved 29 December 2013.

18. Petticrew, M. P.; K. Lee; M. McKee. Type A behavior pattern and coronary heart disease: Philip Morris's "crown jewel". American Journal of Public Health. 2012, 102 (11): 2018-2025.
19. Pop-Jordanova N, Zorcec T. Chronic diseases in children and adolescents- some psychological characteristics. Paediatr Croat, 2008; 52:71-76.

20. Pop-Jordanova N, Zorcec T. Age, Gender and Disorder Related Personality Characteristics of Pediatric Patients Measured by Eysenck Personality Questionnaire, Acta Informatica Medica, 2009; 18(4): 208-213.

21. Pop-Jordanova N, Boskovska V. EPI and EPQ: The fuzzy reasoning expert systems in the pediatric psychodiagnostics. Second Baltic Sea Conference on Psychosomatic Medicine, Ronneby, Sweden, 11-14 June, 1995.

22. Pop-Jordanova N., Demerdzieva A. Is the Grossarthsche behavior typology applicable for healthy people, International Journal of Contemporary Applied Sciences, 2016; 3 (3): 158175.

23. Pop-Jordanova N., Trpeski S., Kaftandziev I., Spasov M. The perceived stress in patients and medical staff in traumatology, SYLWAN: english edition, 2015; 159 (3): 336-346.

24. Strójwąs K, Florkowski A, Jeżowska-Smorąg I, Gądek I, Zboralski K, Macander M, Przybyszewska M, Wierzbiński P. Emotional and psychosomatic disorder among female patients undergoing breast cancer diagnosis. Pol Merkur Lekarski. 2016; 39(233) pp. 287-91. 


\title{
Резиме
}

\section{ТИПОВИ НА ЛИЧНОСТ КАЈ ПАЦИЕНТИ \\ СО ТРАУМАТСКИ СКРШЕНИЦИ НА ЕКСТРЕМИТЕТИТЕ}

\author{
Симе Трпески ${ }^{1}$, Нада Поп-Јорданова ${ }^{2}$ \\ ${ }^{1}$ Универзитетска клиника за трауматологија, Медицински факултет, \\ Универзитет „Св. Кирил и Методиј“, Скопје, Република Македонија \\ ${ }^{2}$ Македонска академија на науките и уметностите, Скопје, Република Македонија
}

Тврдењето дека личноста влијае на здравјето не е ново. Според теоретскиот приод на ГросардтМатичек и Ајзенк, главен фактор за здравјето е способноста за саморегулација, која ги ублажува ефектите од некои физички ризични фактори.

Целта на оваа студија е да се проценат карактеристиките на личност кај пациентите хоспитализирани на Клиниката за трауматологија за оперативно лекување на скршеници на екстремитетите. Според наше сознание, ова е прва студија од ваков вид во нашиот регион.

Испитуваниот примерок подразбира две групи: пациенти хоспитализирани за трауматологија поради скршеници на екстремитетите $(\mathrm{H}=30)$ и здрави луѓe $(\mathrm{H=120})$ како контрола, испитувани претходно. Користени се два психометриски теста: Гросардт-Матичековиот прашалник и Ајзенковиот прашалник за личноста. (EPQ).

Добиените резултати покажаа дека пациентите со трауматични фрактури на екстремитетите припаѓаат на „здрав тип 4“ од Гросардт-Матичековата типологија, слично како и контролата. Резултатот корелира со низок невротизам $(\mathrm{H})$ и умерена екстраверзија (Е), според Ајзенковиот прашалник.

Покажавме дека полот и возраста многу влијаат на добиените резултати.

Типот на личност може да влијае на реакциите во животните ситуации, справувањето со стресот и, соодветно, да биде тригер за која било болест, дури и трауматски фрактури.

Клучни зборови: трауматични фрактури, тип на личност, стрес. 